\title{
American
}

Journal of

International

Law

\section{VOLUME 95}

2001

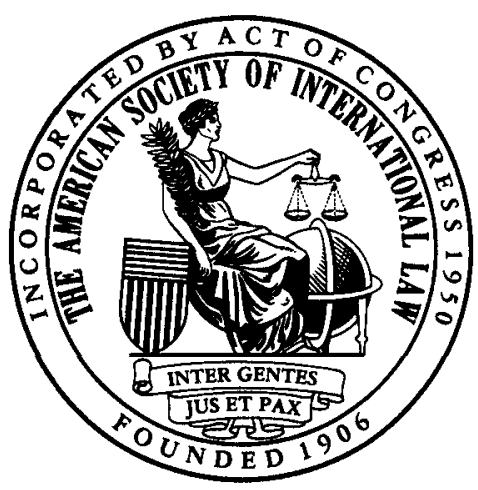

Published by

The American Society of International Law 


\title{
CEP Teaching Fellowships in Eastern Europe, Former Soviet Union, and Mongolia for 2002-03
}

The Civic Education Project (CEP), an international non-profit organization dedicated to university reform in post-communist countries, is accepting applications for its 2002-03 Visiting Faculty Fellowship Program. CEP awards teaching fellowships to faculty and advanced graduate students in the social sciences, law and journalism/media studies. Fellows teach undergraduate students via English.

CEP partner universities are located throughout Central and Eastern Europe, the Former Soviet Union, and Mongolia. Fellows receive a stipend, round-trip air travel, accommodation, health insurance, language tuition, and book allowance. Applications are encouraged from lawyers, as well as faculty and advanced graduate students in all branches of law. Effective deadline for 2002-03 applications is February 152002.

For more information, to see a list of Visiting Fellowships available for 200203 , or to apply directly on-line, please visit our web site: http://www.cep.org.hu

\author{
Civic Education Project
}

1717 Massachusetts Avenue NW, Suite 506 Washington DC 20036

cepdc@ihu.edu, Tel 2026637793

\section{Law and Human Rights}

A Village Destroyed,

\section{May 14, 1999}

War Crimes in Kosovo

Fred Abrahams and Eric Stover

WITH AN INTRODUCTION BY CARROLL BOGERT PHOTOGRAPHS BY GILLES PERESS

"A very important book, offering a revealing examination of how contemporary human rights investigations and international efforts to do justice are transforming the context in which great crimes are committed."

-Aryeh Neier, President of the Open Society Institute $\$ 50.00$ hardcover, $\$ 18.95$ paperback
Gypsy Law

Romani Legal Traditions

and Culture

Walter O. Weyrauch, Editor

This authoritative collection

brings together leading Gypsy and

non-Gypsy scholars to examine

the Romani legal system, an

autonomous body of law based

on an oral tradition and existing

alongside dominant national legal

networks.

$\$ 60.00$ hardcover, $\$ 24.95$ paperback 


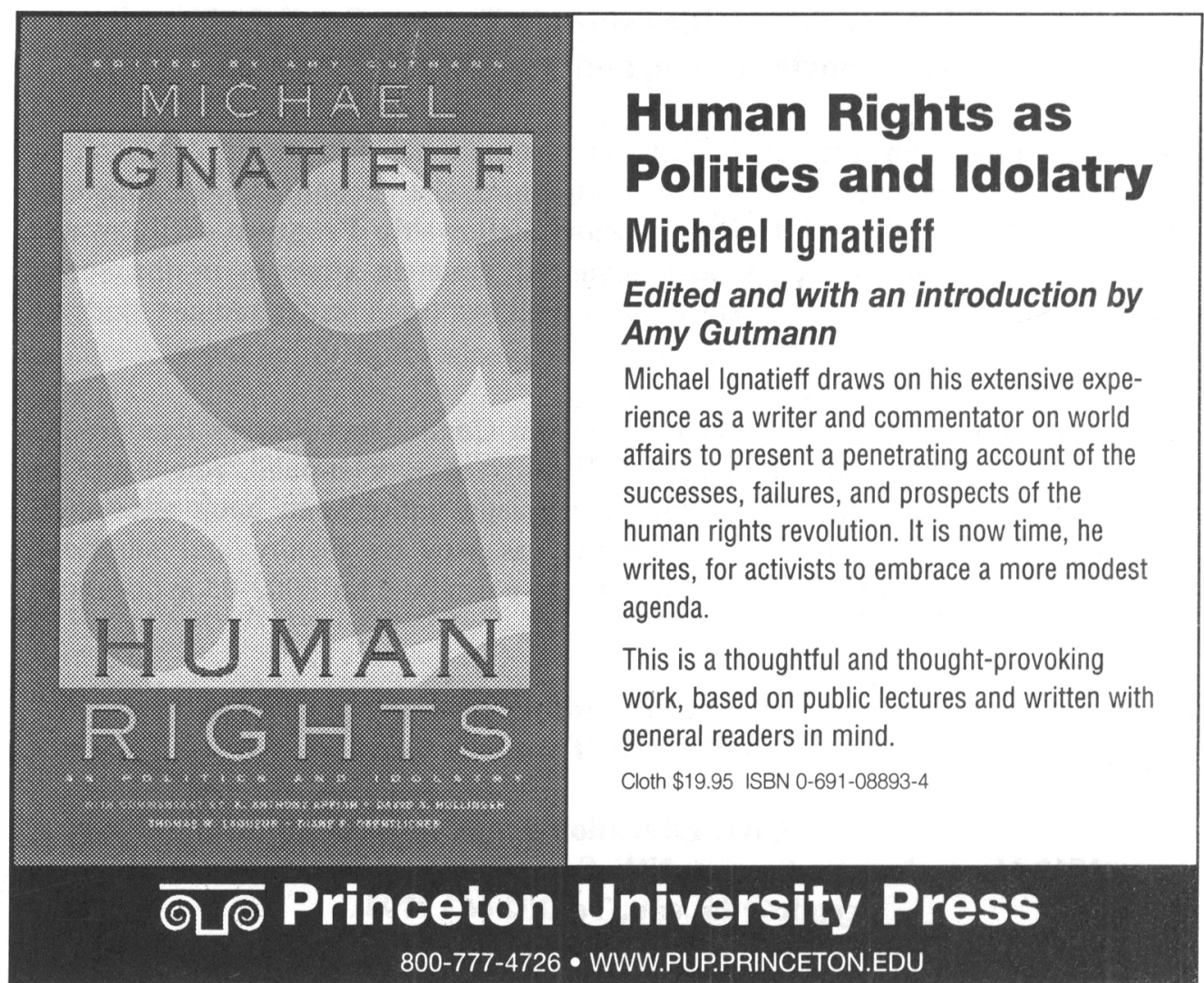

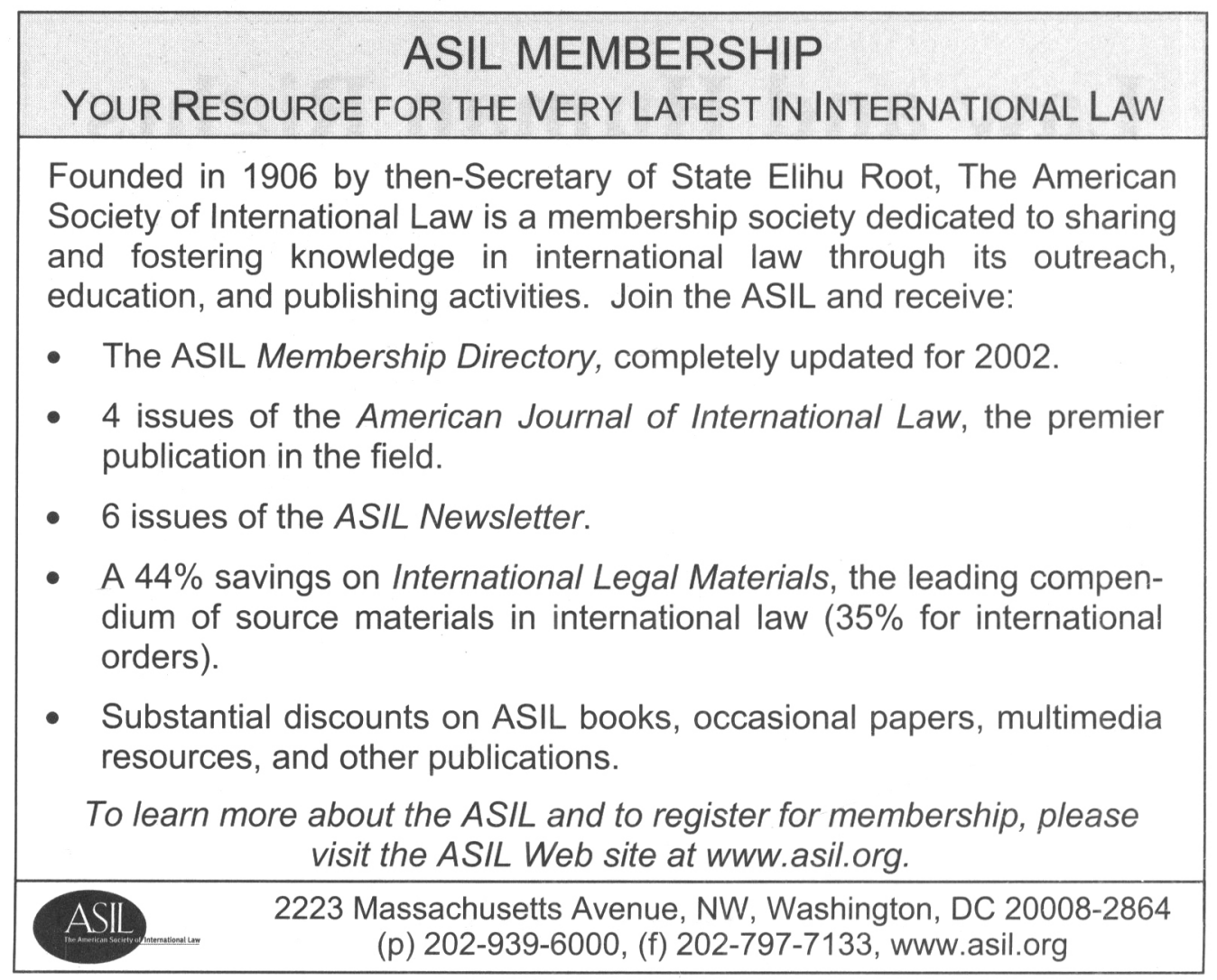




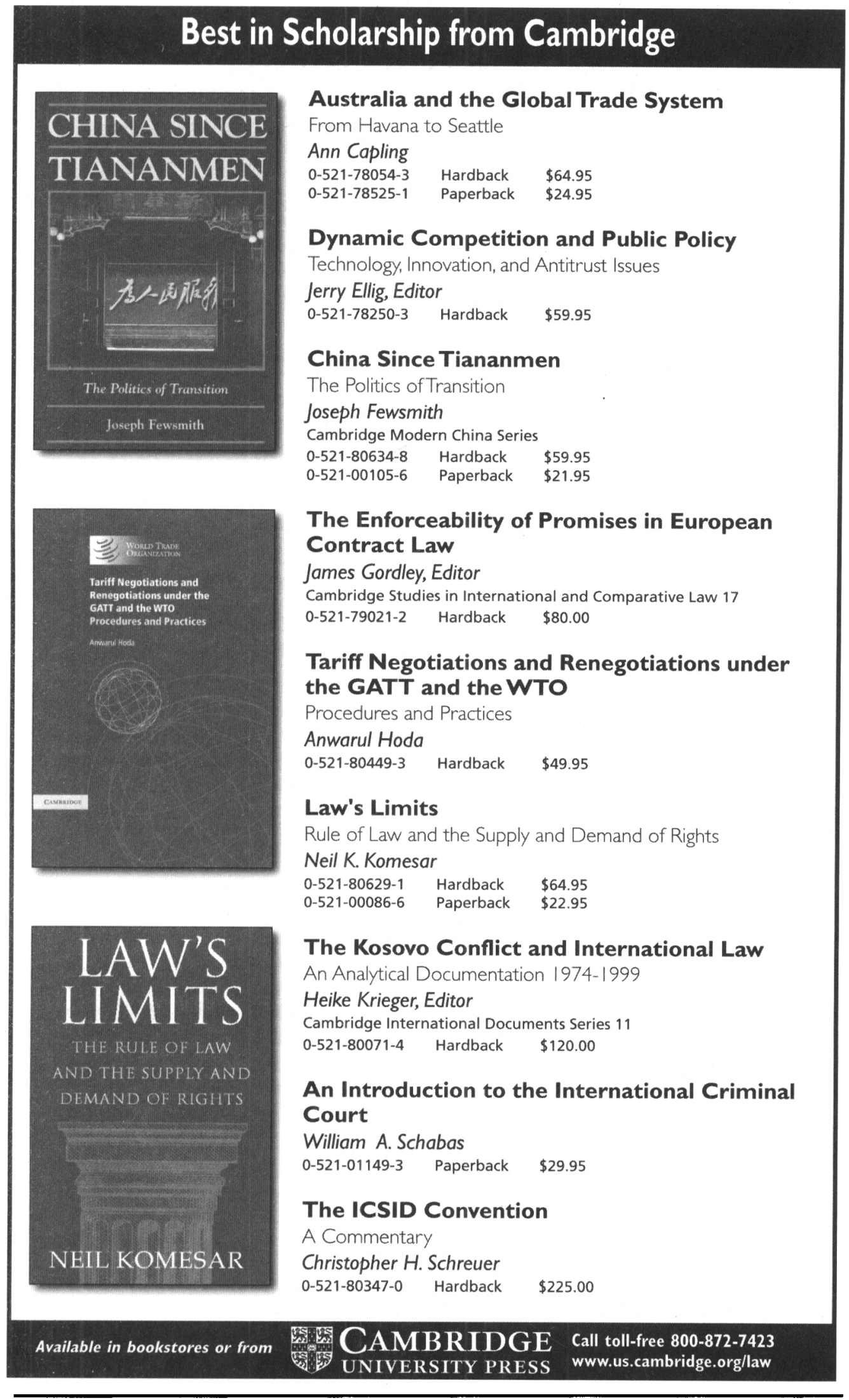




\title{
KLUWER LAW INTERNATIONAL WAR, DISASTER AND CRISIS IN CIVIL SOCIETIES: REACTION AND RESPONSE
}

\author{
Women, Armed Conflict and International Law, by Judith G. Gardam and \\ Michelle J. Jarvis
}

The extent to which international law has affected the status and condition of women in armed conflict has not been adequately treated up to now. The authors look at the particular conditions of women in war and the consequences of deficiencies in international law to address the problem. Their analysis is complemented by suggestions for amelioration and a bibliography.

ISBN 90-411-1640-0, 308 pages, May 2001, USD \$83.

\section{The Reform Process of United Nations Peace Operations: Debriefing and} Lessons, edited by Nassrine Azimi and Chang Li Lin

The Brahimi Report on the successes, disappointments and future of U.N. peacekeeping operations treated the lessons learned from operations such as those in Rwanda, Somalia, Kosovo, East Timor, and the Democratic Republic of the Congo. This title grew out of a two day, closed door conference in Singapore in which scholars, diplomats and military officers discussed, expanded upon--and argued over--the Brahimi Report.

ISBN 90-411-1699-0, 344 pages, September 2001, USD \$97.

\section{The International Aspects of Natural and Industrial Catastrophes (in English} and French), edited by David D. Caron and Charles Leben Recueil des Cours-Colloques

This volume of the Colloquia from The Hague Academy is divided into four parts. An introduction treats international legal aspects of catastrophe; Part I outlines five catastrophes. Part II examines global response to catastrophe, including duties of notification and mitigation. Finally, Part III treats the aftermath of catastrophe, including State responsibility and liability.

The Hague Academy of International Law, ISBN 90-411-1485-8, 900 pages, October $2001, \$ 202$.

\section{Refugee Law in Context: The Exclusion Clause, edited by Peter J. van} Krieken

This "Article 1F Handbook" examines the asylum-seeker with blood on his hands, the asylum-seeker once a terrorist or war criminal who is clearly not eligible under international law for refugee status. This book is an indispensable guide for all those involved with or concerned about asylum seekers, refugees and the upholding of the principles of refugee law.

T.M.C. Asser Press, ISBN 90-6704-118-1, 344 pages, November 1999, USD $\$ 99$. 


\section{THE JOURNALS OF KLUWER LAW INTERNATIONAL}

\section{INFORMATION, OPINION AND COMMENTARY FROM A GLOBAL PERSPECTIVE}

Each Kluwer Law International journal has a home page, with editorial boards, content, archiving, and print and electronic subscriptions. But, as with all Kluwer Law International products, the format is only a path to the content!

International Law FORUM du Droit International: The Journal of the International Law Association/La Revue de l'Association du Droit International This journal covers all aspects of public and private international law with an unmatched interdisciplinary approach. Its authors include both distinguished practitioners and scholars as well as fresh, new voices in international law.

http://www.wkap.nl/journalhome.htm/1388-9036

\section{Criminal Law Forum: The Official Journal of the Society for the Reform of Criminal Law}

Criminal Law Forum treats of criminal law theory, practice, and reform throughout the world. This journal serves the global community of criminal law scholars and practitioners through the publication of original contributions and the dissemination of noteworthy public documents. http://www.wkap.nl/journalhome.htm/1046-8374

\section{Non-State Actors and International Law}

The advent of non-state actors such as intergovernmental organisations, nongovernmental organisations, individuals, peoples, or transnational corporations has changed our outlook on contemporary international law. The object of this journal is to further understanding of non-state actors and their relationship inter pares, and with state actors. It examines these groups as influences on international law and as interveners before administrative tribunals and courts.

http://www.wkap.nl/journalhome.htm/1567-7125

\section{Law and Practice of International Courts and Tribunals}

This new journal aims to provide the reader with articles and information on the law and practice of international courts and tribunals with particular emphasis on procedural questions. The Law and Practice of International Courts and Tribunals will also offer the interpretation and application of Rules of Procedure and constitutional documents, which can be found in legal opinions, written and oral pleadings and the legal literature.

Contact us at kli-nyc@wkap.com for further information about this journal.

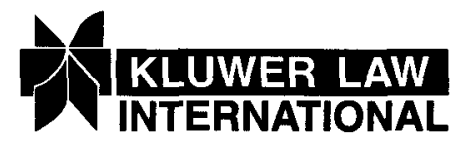

The Hague • London • New York

Kluwer Law International

233 Spring Street, 7th Floor

New York NY 10013

Tel: 212-620-8407 Fax:212-647-1898

E-mail: kli-nyc@wkap.com 
New in paperback!

THE ROLE OF LAW IN INTERNATIONAL POLITICS

Essays in International Relations and International Law

Edited by MICHAEL BYERS

This important book contains original essays by eighteen leading scholars and practitioners. Together they examine the role that international law plays in international politics at the turn of the century. 2000 (paper 2001 ) $376 \mathrm{pp}$. paper $\$ 22.95$ doth $\$ 80.00$

\section{Forthcoming!}

\section{SCEPTICAL ESSAYS ON HUMAN RIGHTS}

Edited by TOM CAMPBELL, KEITH EWING, and ADAM TOMKINS

This collection raises profound concerns about the entrenchment of human rights in UK law.

This is the first book to take a skeptical approach to recent developments in human rights law. November $2001420 \mathrm{pp}$. paper $\$ 24.95$ cloth $\$ 80.00$

\section{JUST WAR OR JUST PEACE?}

Humanitarian Intervention and International Law SIMON CHESTERMAN

This groundbreaking book seeks to determine whether states have the right to intervene in foreign civil conflicts for humanitarian reasons. It puts humanitarian intervention-including NATO's action in Kosovo-in its proper legal perspective. $2001 \quad 328$ pp. $\$ 70.00$

\section{THE EMPOWERED SELF}

Law and Society in the Age of Individualism

THOMAS M. FRANCK

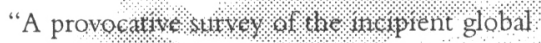
politics I. 100 f fnds deep fissures in the cold brittle crust' of national sovereignty that still covers much of the planet?

- Max Frankel, THe New York Times

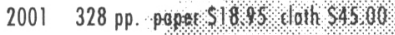

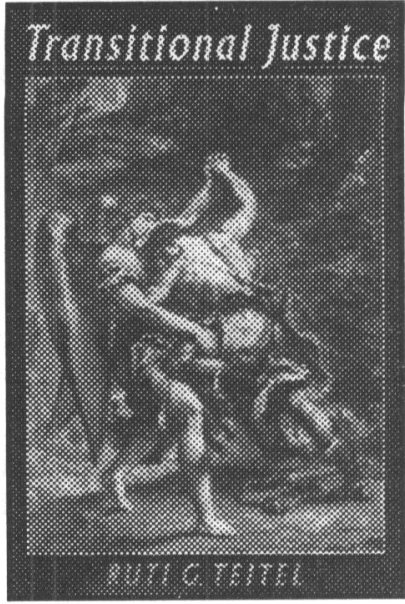

Forthcoming in paperback!

TRANSITIONAL JUSTICE

RUTI G. TEITEL

"A valuable contribution to the growing body of scholarly literature."

- New York Review of Books

"Filled with fresh ideas and interesting, provoking perspectives.... Essential reading for all those facing the complexities of transition in practice."-Times Higher Education Supplement 2000 (paper December 2001$) 304$ pp. paper $\$ 17.95$ cloth $\$ 35.00$

\section{DISCRIMINATION AND HUMAN RIGHTS}

The Case of Racism

Edited by SANDRA FREDMAN and PHILIP ALSTON

This set of essays looks at the role of human rights law in combating racism. Topics covered include the right to equality in the context of racism; multi-culturalism, ethnicity, and group rights; international instruments to address racism, including EU directives; and the problem of race hatred on the Internet. 2001. 300 pp. paper $\$ 24.95$ cloth $\$ 65.00$

\section{OXFORD} UNIVERSITY PRESS
Prices are subject to change and apply only in the US. To order, or for more information, please call 1-800-451-7556. In Canada, call 1-800-387-8020. Visit our website at www.oup.com 


\section{New Titles from Transnational Publishers}

\section{TERRORISM AND THE LAW}

Edited by Yonah Alexander and Edgar H. Brenner

The internationalization and brutalization of modern terrorism makes it very clear that we have entered into an age of super and cyber terrorism with its serious implications for national, regional, and global security concerns. The legal response to this challenge is critical.

Contributors to this volume focus on a broad range of relevant topics (e.g., definitions; human rights; ethnic, racial, and religious intolerance and violence). Appendices contain selected legislation, treaties, and cases.

2001. ISBN 1-57105-243-7. Paperback/184 pages. Price: $\$ 28.50$.

\section{INTERNATIONAL TERRORISM: \\ Multilateral Conventions (1937-2001)}

Edited by $M$. Cherif Bassiouni

"Terrorism" has never been defined in any international convention. Its political content-particularly the fact that much of what we call "terrorism" is state-conducted or state-sponsored-has led to the restriction of the term in international criminal law to strategies of violence by individuals or small groups. Nonetheless, an extensive body of law designed to control international terror violence has come into being. MULTILATERAL CONVENTIONS includes all relevant conventions adopted since the League of Nations Convention of 1937.

2001. ISBN 1-57105-149-X. Hardcover/638 pages. Price: $\$ 145.00$.

\section{INTERNATIONAL TERRORISM:}

\section{A Compilation of U.N. Documents (1972-2001)}

Edited by M. Cherif Bassiouni

Vital legal instruments are gathered together for the first time in this definitive two-volume set. The only published source of all United Nations documentation since 1972 on the subject of "terrorism"-including all 180 reports and resolutions adopted since that date and up to June 2001.

2001. ISBN 1-57105-227-5. 2 volumes, hardcover/1900 pages. Price: $\$ 295.00$.

\section{ANTI-PERSONNEL MINES UNDER HUMANITARIAN LAW: A View from the Vanishing Point}

\section{Stuart Maslen}

This volume considers in depth the various customary and conventional legal regimes applicable to the use of anti-personnel mines. It assesses how successfully humanitarian law-the "vanishing point" of international law-has managed to reduce the threat to civilians from anti-personnel mines, and identifies lessons for the future regulation of other conventional weaponry. All involved with the global effort to control and eliminate anti-personnel mines as well as the policy-makers who are concerned about the devastation resulting from the widespread deployment of these arbitrary weapons need to familiarize themselves with the information presented in this timely work.

\section{Fall 2001. ISBN 1-57105-244-5. Paperback/327 pages. Price: \$85.00.}

410 Saw Mill River Road Ardsley, NY 10502 Toll free $800914-8186$
FAX 914-693-4430

info@transnationalpubs.com www.transnationalpubs.com 
The ASIL's $96^{\text {th }}$ Annual Meeting will address the twin themes of the legalization of international relations and the internationalization of legal relations. These themes capture current discussions about the growing role of rules in the conduct of international affairs and the impact of globalization on legal relations. Representing two sides of the same coin, the trends toward legalizing and internationalizing may well herald a golden age for international law, or may be just the opposite-international law's absorption by international relations or mainstream law. Join more than 1,000 practitioners, scholars, and students as they discuss these trends and their impact on the future of international law.

\section{CONFERENCE REGISTRATION}

Master ID \#

Registrant

\begin{tabular}{llll}
\cline { 2 - 3 } & Last name & First name & M.I. \\
Affiliation & & & \\
\cline { 2 - 3 }
\end{tabular}

Address

City/State/Zip

Country

Phone

Fax

E-mail

ASIL uses the information you are providing to maintain lists of its members, subscribers and Annual Meeting participants. From time to time, ASIL makes these lists available to third parties. For further information, contact the Services Group at (202)939-6000 or by e-mail at services@asil.org.

$\square$ Check here if you do not wish your name and contact information to be made available to entities other than ASIL.

$\square$ Check here if you need special assistance (ADA).

$\square$ Check here if you have special dietary requirements.

Please describe:

\section{PAYMENT}

$\square$ Check payable to ASIL (drawn in \$US on a US bank)

$\square$ Visa $\square$ MasterCard $\square$ American Express

Card Number

Exp. Date 1

Name on Card

Signature

\section{REGISTRATION FEES:}

$\underline{\underline{B e f o r e}} \quad \underline{\text { After }}$

$\underline{\text { After }}$

$\underline{3 / 1 / 02}$

(onsite)

$\begin{array}{llll}\text { Members } & \square \$ 250 & \square \$ 300 & \square \$ 325 \\ \text { Nonmembers } & \square \$ 450 & \square \$ 525 & \square \$ 550 \\ \text { One-day } & \square \$ 100 & \square \$ 100 & \square \$ 150 \\ \text { Students } & \square \$ 0 & \square \$ 0 & \square \$ 0 \\ \text { A copy of your school registration is required. }\end{array}$

Panelists $\square \$ 125 \square \$ 125 \square \$ 125$ $\square \$ 0$ if you only attend your panel.

Groups (8) $\square \$ 1,500 \quad \square \$ 1,800 \quad$ N/A Please attach a separate sheet listing the attendees.

\section{FOOD FUNCTIONS:}

*No on-site ticket sales*

President's Reception-Wed. March $13 \square \square$

Box Lunches: $\square$ Thursday, March $14 \square \$ 20$

$\square$ Friday, March $15 \quad \square \$ 20$

Rededication Lunch Sat. March $16 \quad \square \$ 0$

WILIG Lunch-Thursday, March $14 \quad \square \$ 35$

Annual Dinner--Friday, March $15 \quad \square \$ 65$

TOTAL: $\$$

Please visit our Web site <www.asil.org > for further information.

\section{Meal Functions}

Tickets for meal functions must be purchased prior to the Annual Meeting, as guest counts for meals must be given to the hotel well in advance of the function. Therefore, there will be NO ON-SITE PURCHASE of meal tickets. ASIL is not responsible for last-minute speaker changes. NO REFUNDS for meal functions will be made after Monday, February 18,2002. ASIL cannot replace lost meal tickets.

\section{Hotel Accommodations}

To arrange for hotel aocommodations, please contact the Washington Monarch directly at (202) 4292400 or (877) 222-2266. ASIL is not responsible for arranging hotel accommodations. Discounted room rates are available until Tuesday, February 19, 2002 after which time the discounted

room block will be released. In order to qualify for the discounted room rate, please indicate when making your reservation that you are attending ASIL's Annual Meeting

\section{Cancellations}

A $\$ 45$ processing fee will be deducted from registrations canceled by Monday, February 18, 2002. Refunds will not be made on registrations canceled after this date; however, substitutions are allowed.

\section{Mail to:}

ASIL

P.O. Box 0164

Washington, DC 20055-0164
Fax to:

(202) 797-7133

(Please include creait

card information). 


\section{Launcbing the Second Century}

\section{LAUNCHING THE SECOND CENTURY will create}

new Information and Learning Centers at Tillar House, the Society's headquarters in Washington, DC. The \$2 million campaign is anchoring new Society outreach and information programs ... to enhance the ASIL's role as a hub for sharing knowledge and to improve your access to international law information.

\section{"For our field, and the organization that leads it."}

- Judge Stephen M. Schwebel Honorary Chairman Second Century Campaign

Help the organization that leads our field. Contribute to the ASIL's Launching the Second Century Campaign. 


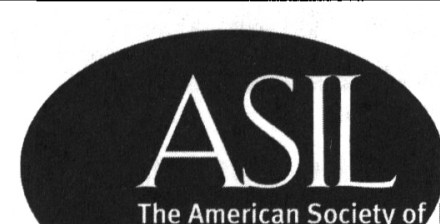

The American Society of International Law

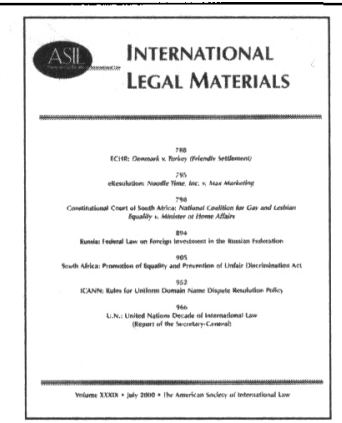

\section{Problem Solved.}

Subscribe to International Legal Materials, and solve a few modern problems:

$>$ Web sites come and go, taking the usefulness of your citations with them.

$>$ Most libraries are not repositories of U.N. Treaties and arbitral decisions.

$>$ You cannot write notes in the margins on your computer screen.

$>$ Information is not at your fingertips when Internet searches yield 2,349 results.

Visit the ASIL Web site at <www.asil.org>, sign up for ILM in 2002, and relax.

...problem solved.

The American Society of International Law, 2223 Massachusetts Avenue, $N W$, Washington, DC 20008, 202-939-6000 (p), 202-797-7133 (f), www.asil.org (u) 


\section{United Nations Publications}

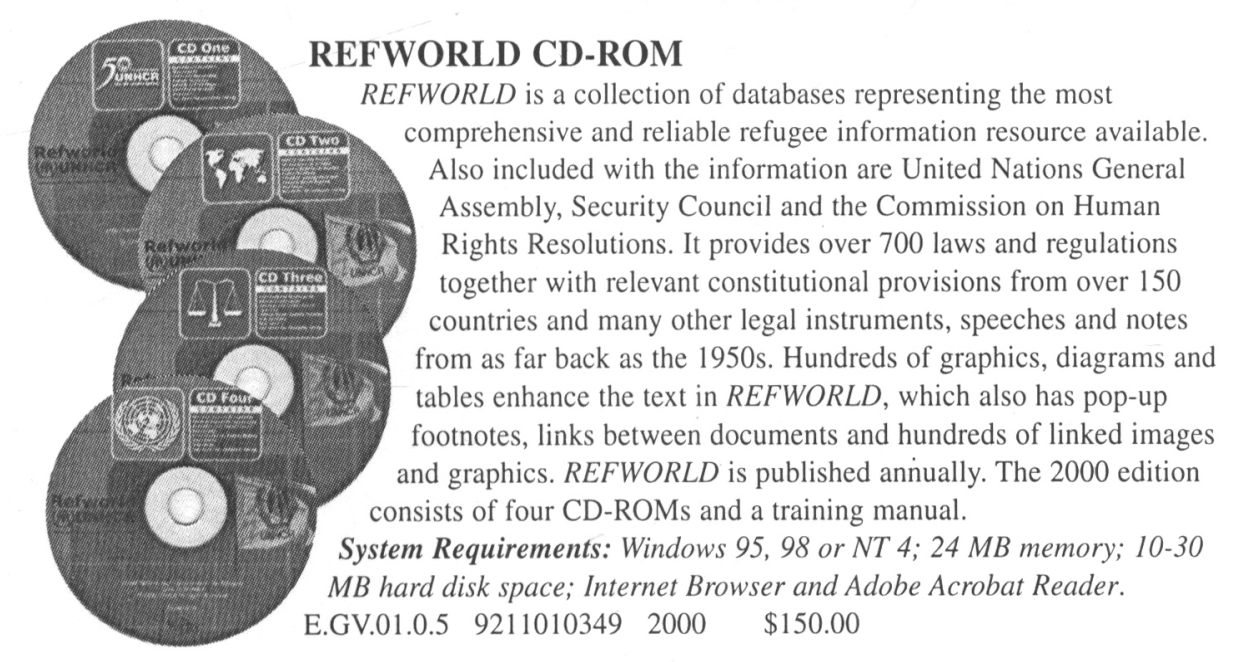

\section{Arbitration and Alternative Dispute Resolution: How to Settle International Business Disputes}

With the acceleration of cross-border trade, business operators are exposed to new partners, countries, cultures and trade practices. Business dealings naturally give rise to disputes. This publication sets out the different alternatives to State proceedings that may be used to prevent or settle business disputes in an international context.

E.01.III.T.5 9291371726 284pp. $\$ 50.00$

\section{Children's Rights Glossary}

This Glossary is published as a companion volume to the International Children's Rights Thesaurus. It aims to provide a detailed key to the specialized terminology used in the field of children's rights, and particularly in the Convention on the Rights of the Child(CRC). The Glossary concludes with a thematic listing of selected international instruments relevant to children's rights. It is hoped that the Glossary will be useful in promoting a better understanding of children's rights terminology among specialists and non-specialists alike.

E.01.XX.8 8885401589 48pp. $\$ 20.00$

\section{Yearbook of the International Court of Justice}

This is an annual record of the work of the Court from 1 August - 31 July each year. It discusses cases before the Court pertaining to subjects such as territorial rights, law of the sea and treaty interpretation. A wide range of topics has been covered in the years and each issue contains a chapter describing the publications issued by the Court during that year.

E.ICJ/752 $9211700760 \quad 1998 / 99 \quad$ No.53 380pp. $\$ 35.00$ 


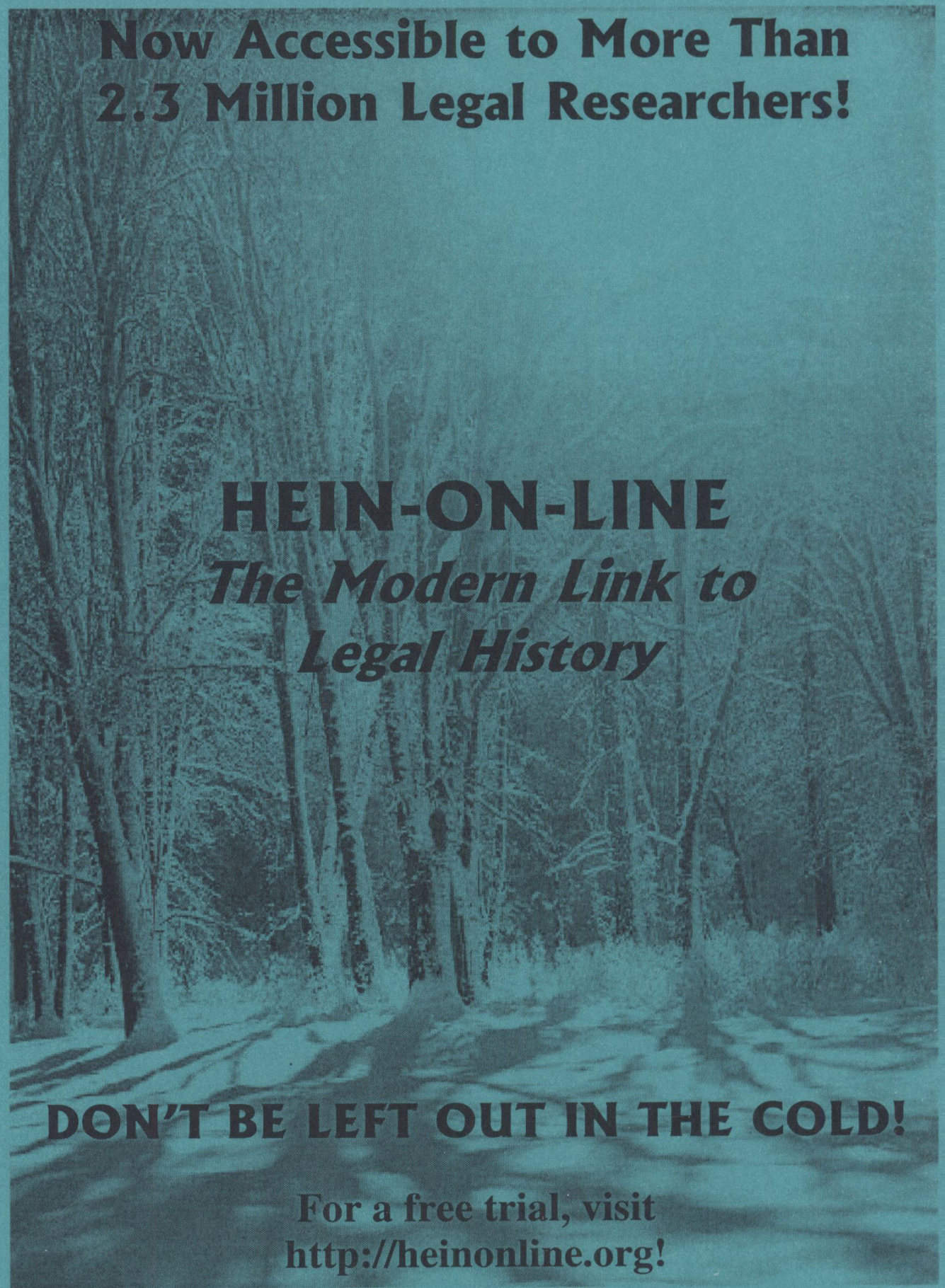

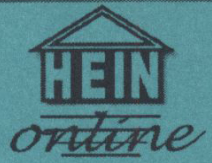

The Modern Link to Legal History

\section{WILLIAM S. HEIN \& CO., INC. Primus Inter Pares}

1285 Main Street, Buffalo, New York 14209

(716) $882-2600$ - TOLL FREE $(800) 828-7571$ - Fax (716) 883-8100

E-Mail heinonline@wshein.com — Web Site http://hwinonline.org 